\title{
BMJ Global Health Life expectancy and disparities in survival among HIV-infected people receiving antiretroviral therapy: an observational cohort study in Kathmandu, Nepal
}

\author{
Dharma N Bhatta, ${ }^{\oplus 1}$ Ruchi Adhikari, ${ }^{2}$ Sushil Karki, ${ }^{3}$ Arun K Koirala, ${ }^{4}$ \\ Sharada P Wasti ${ }^{5}$
}

To cite: Bhatta DN, Adhikari R, Karki S, et al. Life expectancy and disparities in survival among HIV-infected people receiving antiretroviral therapy: an observational cohort study in Kathmandu, Nepal. BMJ Global Health 2019:4:e001319. doi:10.1136/ bmjgh-2018-001319

Handling editor Alberto L Garcia-Basteiro

- Additional material is published online only. To view please visit the journal online (http://dx.doi.org/10.1136/ bmjgh-2018-001319).

Received 19 November 2018 Revised 1 April 2019 Accepted 20 April 2019
Check for updates

\section{Author(s) (or their} employer(s)) 2019. Re-use permitted under CC BY-NC. No commercial re-use. See rights and permissions. Published by BMJ.

For numbered affiliations see end of article.

Correspondence to Dr Dharma N Bhatta; dnbhatta@yahoo.com

\section{ABSTRACT}

Introduction The advent of antiretroviral therapy (ART)

has dramatically slowed down the progression of HIV. This study assesses the disparities in survival, life expectancy and determinants of survival among HIV-infected people receiving ART.

Methods Using data from one of Nepal's largest population-based retrospective cohort studies (in Kathmandu, Nepal), we followed a total of 3191 HIVinfected people aged 15 years and older who received ART over the period of 2004-2015. We created abridged life tables with age-specific survival rates and life expectancy, stratified by sex, ethnicity, CD4 cell counts and the WHOclassified clinical stage at initiation of ART.

Results HIV-infected people who initiated ART with a CD4 cell count of $>200$ cells $/ \mathrm{cm}^{3}$ at 15 years had $27.4(22.3$ to 32.6) years of additional life. People at WHO-classified clinical stage I and 15 years of age who initiated ART had 23.1 (16.6 to 29.7) years of additional life. Life expectancy increased alongside the CD4 cell count and decreased as clinical stages progressed upward. The study cohort contributed 8484.8 person years, with an overall survival rate of 3.3 per 100 person years $(95 \% \mathrm{Cl} 3.0$ to 3.7$)$. Conclusions There are disparities in survival among HIVinfected people in Nepal. The survival payback of ART is proven; however, late diagnosis or the health system as a whole will affect the control and treatment of the illness. This study offers evidence of the benefits of enrolling early in care in general and ART in particular.

\section{INTRODUCTION}

Mortality and morbidity rates have decreased and life expectancy has increased with the scale-up of antiretroviral therapy (ART). ${ }^{1}{ }^{2}$ Remarkable progress in the life expectancy of HIV-infected populations has been reported among developed countries after the initiation of ART. ${ }^{3-5}$ However, very few studies find the same effect of ART on life expectancy in resource-limited countries. ${ }^{26-8}$

\section{Key questions}

What is already known?

- Mortality and morbidity decreased and life expectancy increased with the scale-up of antiretroviral therapy.

What are the new findings?

- Life expectancy varied by sex, CD4 cell count and clinical stage, and that access to antiretroviral therapy greatly improved life expectancy, particularly among patients with high baseline CD4 cell count.

- Early diagnosis and treatment are the major challenges to reduce survival disparities among HIVinfected people in low-income and middle-income countries.

What do the new findings imply?

- Improvements in the quality of care and comprehensive strategies and plans for early detection and treatment for patients with HIV are needed.

It is important to estimate the life expectancy of HIV-infected people to monitor the progress of available ART; to observe the social, economic and demographic impacts of HIV; to estimate costs of HIV care; to inform people when treatment needs to begin; and to estimate other family settlements (manage assets for spouse or children). ${ }^{39}$ This is important to policy makers and service providers who seek to improve the outcomes of HIV-infected people and are interested in reducing disparities in their survival and life expectancy through ART. ${ }^{10}$ Life expectancy among HIV-infected populations varies considerably by gender, age and ethnicity, and between developed and resource-limited countries. ${ }^{1112}$ Literature related to life expectancy among HIV-infected people receiving ART is not available in Nepal. Estimates of the 
life expectancy and survival rates of HIV-infected people in Nepal can inform the development of good-quality healthcare and reduce preventable mortality in the context of freely available treatment in Nepal. We aim to estimate the life expectancy of HIV-infected people who received ART in Nepal, disaggregated by age, gender, ethnicity, CD4 cell count and the WHO clinical stage on initiating ART.

\section{METHODS}

\section{Study design and participants}

In a retrospective observational cohort study, we used data from the government-run Sukraraj Tropical and Infectious Disease Hospital (STIDH), Kathmandu District. This hospital has the largest ART centre in Nepal and is part of the National Centre for AIDS and STD Control ${ }^{13}$ which develops policies and strategies related to HIV/AIDS and develops ART within the country. The national ART programme in Nepal comprises bimonthly follow-up visits from the medical team in support of ART treatment, the treatment of comorbidities, and estimation of the CD4 cell count every 6 months, viral load measurement 1 year after the initiation of ART, and other care and support. Demographic and clinical records on ART enrolment and vital or mortality records during follow-up sessions were obtained from electronic records, the ART register and individual chart records. People from around the country come to this centre for HIV diagnosis, care, support and treatment services. This centre has provided multidisciplinary services related to HIV/AIDS since $2004^{14}$ and started recording data prospectively that year.

In this study, we included a total of 3191 eligible HIV-infected adults who received ART between 2 February 2004 and 29 March 2015; who had a record of follow-ups (patients were excluded who started ART and then did not return for the first follow-up scheduled in 1 month); and who were aged 15 years or older at enrolment into ART. All the people who tested HIV-positive were monitored through their subsequent registration in the pre-ART register, ART register and individual chart records.

The routinely maintained individual data from the Ministry of Health, STIDH and ART centre, Nepal, were used for analysis in this study.

\section{Patient and public involvement statement}

There was patient or public involvement in this study. However, we used secondary data from patient records.

\section{Procedures}

The data were collected from standard medical record registers, which include details on all confirmed HIV-positive clients who visit the ART centre. The registration number in the ART register was used to track the patient's HIV care and ART record files. Survival time was calculated in months using the date ART was started until date of death, 3-month absence, transfer out or other means of exit from the study, transfer to another health facility, failure to follow up, or death. All clinical, ART and mortality-related data were verified from individual records and ART registers at the ART centre. All deaths related to HIV were considered as mortality. Individuals who missed three consecutive monthly visits for general health check-ups and collection of ART drugs were considered as lost to follow-up. The demographic characteristics included in the study were sex (male and female), age (5-year categories for ages $15-59$ years and $\geq 60$ years for the life expectancy table), ethnicity (coded as non-indigenous and indigenous) and residence (valley: people who came from the surrounding districts of the study area, namely Kathmandu, Bhaktapur and Lalitpur; hill: mountainous areas; terai: plain or lowland areas-hill and terai regions are rural areas from the valley region). Clinical variables at the initiation of ART included CD4 cell counts (categorised as $\leq 50,>50-100,>100-200,>200$ cells $/ \mathrm{cm}^{3}$ ), WHO clinical stages (I, II, III, IV), and duration between HIV diagnosis and initiation of ART.

\section{Statistical analysis}

Survival rates were expressed as the number of deaths per 100 person years. Survival probability was stratified by sex, age, residence, ethnicity, baseline CD4 cell counts and WHO-classified clinical stage.

Survival time was calculated in months using the date ART was started until the date of death, 3-month absence, transfer out or other means of exit from the study. Cumulative mortality and survival probability were estimated using the Kaplan-Meier model, and survival curves were compared using $\mathrm{p}$ values. The Kaplan-Meier method presents survival distribution with graphical presentation, product limit calculations and survival probabilities. The log-rank test was used to compare survival functions. Distribution-free methods were applied for statistical comparison.

The proportional hazard assumption was used to assess the assumption for independent variables fit in the model. Cox proportional hazard models were used to calculate the hazard of mortality with a $95 \%$ CI. We used both univariate and multiple Cox regression analyses for unadjusted and adjusted HRs. Sex, age, ethnicity, residence, CD4 cell count, WHO-classified clinical stage, and duration between diagnosis and ART initiation were adjusted for the analysis. A global test was used to assess the violation of assumptions with any variable in the adjusted model. Because of very low level of missing covariate data, we used listwise deletion.

The study used the method developed by Chiang ${ }^{15}$ for abridged life tables, created from age-specific survival rates. Chiang's ${ }^{15}$ life table estimates the life expectancy of a particular cohort of people and indicates the average number of additional years that they will live after that age. The life expectancy table was stratified by sex, ethnicity, WHO-classified clinical stage and CD4 cell count, and presented by age group. 
Fundamental to the assessment of life expectancy throughout these life tables is the evaluation of survival rates. We removed data on people lost to follow-up to calculate life expectancy as a sensitivity analysis (online supplementary table 1$)$.

$P$ values $<0.05$ were considered statistically significant, and all significance tests were two-sided. Analyses were prepared with R and Microsoft Excel.

\section{RESULTS}

In this analysis, a total of 3191 eligible ART recipients were included, out of whom 344 (10.8\%) died, 397 (12.4\%) did not follow up, $1053(33.0 \%)$ were transferred out to other ART centres and 1397 (43.8\%) were alive as of 29 March 2015.

Table 1 shows the background and clinical characteristics of HIV-infected people who received ART. The overall study cohort follow-up contributed 8484.8 person years with a total mortality rate of 3.3 per 100 person years (95\% CI 3.0 to 3.7 ) (table 1 ).

Figure 1 shows the overall survival probability among HIV-infected people receiving ART over the follow-up period (figure 1). Figure 2 shows the survival probability among gender, ethnicity, WHO clinical stages and CD4 cell count.

Table 1 Background and clinical characteristics

\begin{tabular}{|c|c|c|c|c|}
\hline Characteristics & $\begin{array}{l}\text { Total } \\
\mathrm{N}=3191(\%)\end{array}$ & $\begin{array}{l}\text { Death } \\
\mathrm{n}=344(\%)\end{array}$ & $\begin{array}{l}\text { Others } \\
n=2847(\%)\end{array}$ & $\begin{array}{l}\text { Mortality rate per } 100 \\
\text { person years at risk } \\
(95 \% \mathrm{Cl})\end{array}$ \\
\hline \multicolumn{5}{|l|}{ Gender } \\
\hline Male & $1986(62.2)$ & $244(70.9)$ & $1742(61.2)$ & 4.0 (3.4 to 4.5$)$ \\
\hline Female & $1205(37.8)$ & $100(29.1)$ & $1105(38.8)$ & 2.4 (1.9 to 3.9 ) \\
\hline \multicolumn{5}{|l|}{ Ethnicity } \\
\hline Non-indigenous & $1396(43.7)$ & $143(41.6)$ & $1253(44)$ & 3.2 (2.6 to 3.8$)$ \\
\hline Indigenous & $1795(56.3)$ & $201(58.4)$ & $1594(56)$ & 3.5 (3.0 to 4.1$)$ \\
\hline $\begin{array}{l}\text { Age at ART initiation, } \\
\text { median (IQR) }\end{array}$ & $36(32-42)$ & $37(32-43)$ & $36(32-42)$ & \\
\hline$\leq 36$ years & $1597(50)$ & $170(49.4)$ & $1427(50.1)$ & 3.6 (3.1 to 4.2 ) \\
\hline$>36$ years & $1594(50)$ & $174(50.6)$ & $1420(49.9)$ & 3.1 (2.7 to 3.7 ) \\
\hline \multicolumn{5}{|l|}{ Residence } \\
\hline Valley & $916(28.7)$ & $122(35.5)$ & 794 (27.9) & $3.1(2.5$ to 3.7$)$ \\
\hline Hill & $1280(40.1)$ & $126(36.6)$ & $1154(40.5)$ & 3.2 (2.6 to 3.8$)$ \\
\hline Terai & 995 (31.2) & 96 (27.9) & 899 (31.6) & 4.2 (3.3 to 5.3 ) \\
\hline \multicolumn{5}{|l|}{ Clinical stage } \\
\hline Stage I & $750(23.5)$ & 42 (12.2) & 708 (24.9) & 1.8 (1.3 to 2.5$)$ \\
\hline Stage II & $845(26.5)$ & 39 (11.3) & $806(28.3)$ & 1.3 (0.9 to 1.9$)$ \\
\hline Stage III & $1086(34.0)$ & $123(35.8)$ & $963(33.8)$ & 3.7 (3.1 to 4.5$)$ \\
\hline Stage IV & $510(16.0)$ & $140(40.7)$ & $370(13)$ & 10.2 (8.4 to 12.3$)$ \\
\hline $\begin{array}{l}\text { CD4 cell count (cells/ } \\
\left.\mathrm{cm}^{3}\right),{ }^{*} \text { median (IQR) }\end{array}$ & 132 (64-201) & $85(41-140)$ & $139(70-208)$ & \\
\hline$\leq 50$ & $523(18.4)$ & $91(28.7)$ & $432(17.1)$ & 6.0 (4.7 to 7.5$)$ \\
\hline $51-100$ & $570(20.0)$ & $93(29.3)$ & 477 (18.9) & 5.2 (4.1 to 6.6$)$ \\
\hline $101-200$ & $1033(36.3)$ & $103(32.5)$ & $930(36.8)$ & 2.8 (2.2 to 3.4$)$ \\
\hline$>200$ & $721(25.3)$ & $30(9.5)$ & 691 (27.3) & 1.1 (0.8 to 1.7$)$ \\
\hline $\begin{array}{l}\text { Duration of ART } \\
\text { initiation, median (IQR) }\end{array}$ & $21(1-54)$ & $3(1-13.2)$ & $24(2-58)$ & \\
\hline$\leq 3$ months & $956(30)$ & $184(53.5)$ & $772(27.1)$ & 311.9 (261.6 to 372.0$)$ \\
\hline$>3-6$ months & $174(5.5)$ & 40 (11.6) & $134(4.7)$ & 55.9 (41.0 to 76.2$)$ \\
\hline$>6-12$ months & $239(7.5)$ & $30(8.7)$ & $209(7.3)$ & 16.2 (11.3 to 23.1$)$ \\
\hline$>12-24$ months & $395(12.4)$ & $36(10.5)$ & 359 (12.6) & 5.6 (4.0 to 7.8$)$ \\
\hline$>24$ months & $1427(44.7)$ & $54(15.7)$ & $1373(48.2)$ & 0.7 (0.5 to 0.9 ) \\
\hline
\end{tabular}

*Missing, overall cohort period: 8484.8 person years; mortality rate per 100 person years (95\% Cl) 3.3 (3.0 to 3.7$)$. P value obtained from $\chi^{2}$ test for categorical variables and Wilcoxon signed-rank for continuous variables.

ART, antiretroviral therapy. 


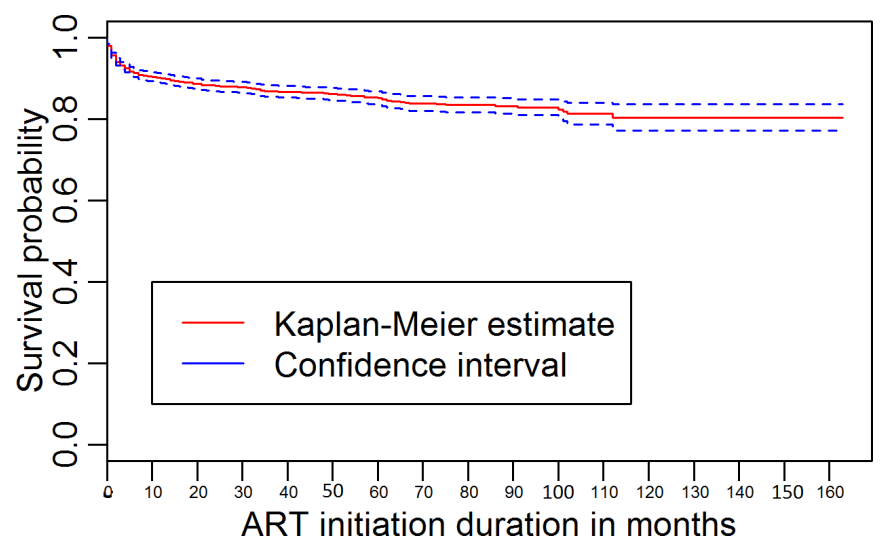

Figure 1 Kaplan-Meier survival estimate with 95\% Cl. ART, antiretroviral therapy.

Table 2 lists the life expectancy (additional year of life) among HIV-infected people after initiation of ART. The overall cohort's life expectancy at 20 years of age was 7.1 (95\% CI 5.5 to 10.4 ) years of additional life and at 40 years of age was 7.5 (7.2 to 9.4 ) years of additional life. The life expectancy of men aged 20 years was 6.4 (3.3 to 9.5) years of additional life compared with 7.7 (3.9 to 11.5) years of additional life for women with the same age. Women had consistently longer life expectancy than men. Life expectancy for indigenous people aged 20 was 6.2 (3.5 to 8.9) years of additional life compared with 7.9 (3.7 to 12.1) years of additional life for non-indigenous people at the same age. Indigenous people had a relatively shorter life expectancy than non-indigenous people. HIV-infected people who initiated ART with a CD4 cell count of $>200$ cells $/ \mathrm{cm}^{3}$ at 20 years had 22.4 (17.3 to 27.6 ) years of additional life compared with 1.3 (1.3 to 1.3 ) years of additional life for those who had CD4 cell count of $\leq 50$ cells/ $\mathrm{cm}^{3}$ at the same age. People at WHO-classified clinical stage I and 20 years of age who initiated ART had 18.1
(11.6 to 24.7) years of additional life compared with 1.2 years of additional life for those who were WHO-classified clinical stage IV at the same age. Life expectancy increased alongside the $\mathrm{CD} 4$ cell count and decreased as clinical stages progressed upward.

HIV-infected women receiving ART were less likely (adjusted HR: 0.80; 95\% CI 0.63 to 1.03) to die compared with HIV-infected men receiving ART, but not statistically significant. People of indigenous ethnicity were more likely $(1.07 ; 0.86$ to 1.34$)$ to die compared with those having non-indigenous ethnicity, but not statistically significant. The risk of death among people over 36 significantly decreased by $26 \%$ ( $0.74 ; 0.59$ to 0.92$)$, compared with people who were less than or equal to 36 years of age. The risk of mortality decreased by $23 \%$ (0.77; 0.60 to 1.01$)$ among people who were from the hilly regions and $8 \%$ (0.92; 0.70 to 1.22$)$ among people who were from the terai region compared with people who were from the Kathmandu valley region, but not statistically significant. The risk of mortality was significantly higher among people who were at WHO clinical stage III $(1.82 ; 1.26$ to 2.62$)$ and stage IV $(3.73 ; 2.58$ to 5.41) compared with people who were at clinical stage I. The risk of mortality was significantly lower among people who had a baseline CD4 cell count of 101-200 cells $/ \mathrm{cm}^{3}(0.71 ; 0.53$ to 0.95$)$ and $>200$ cells $/ \mathrm{cm}^{3}(0.32$; 0.21 to 0.49 ), compared with people who had less than or equal to 50 cells $/ \mathrm{cm}^{3}$ (table 3 ).

\section{DISCUSSION}

This study highlighted the overall survival probability and life expectancy experienced by HIV-infected people receiving ART at any $\mathrm{WHO}$ clinical stage and CD4 cell count over the period of 2004-2015. The study shows the disparities in survival by gender, ethnicity, age, area of residency, WHO clinical stage and $\mathrm{CD} 4$ cell count.
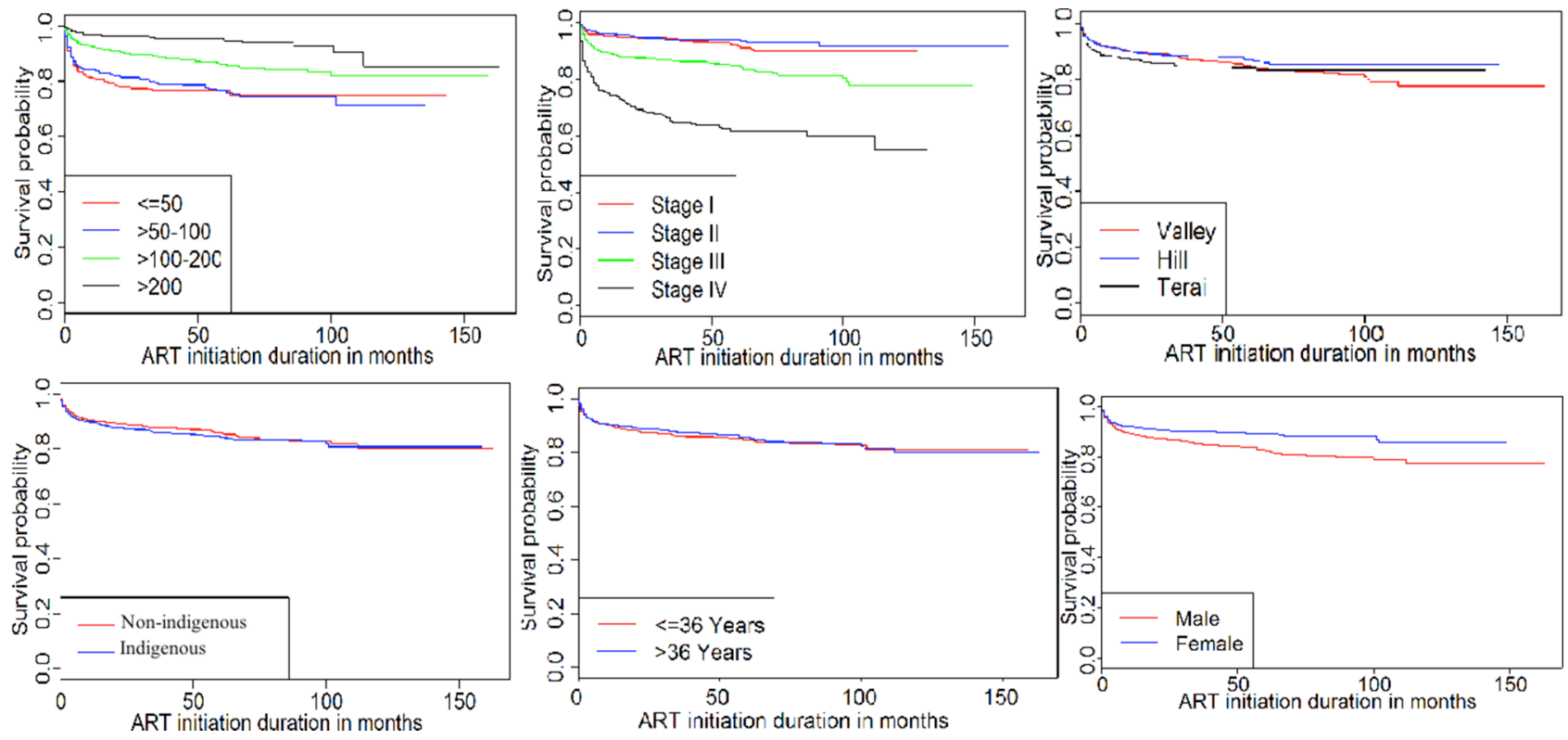

Figure 2 Statistical comparison among survival curves. ART, antiretroviral therapy. 


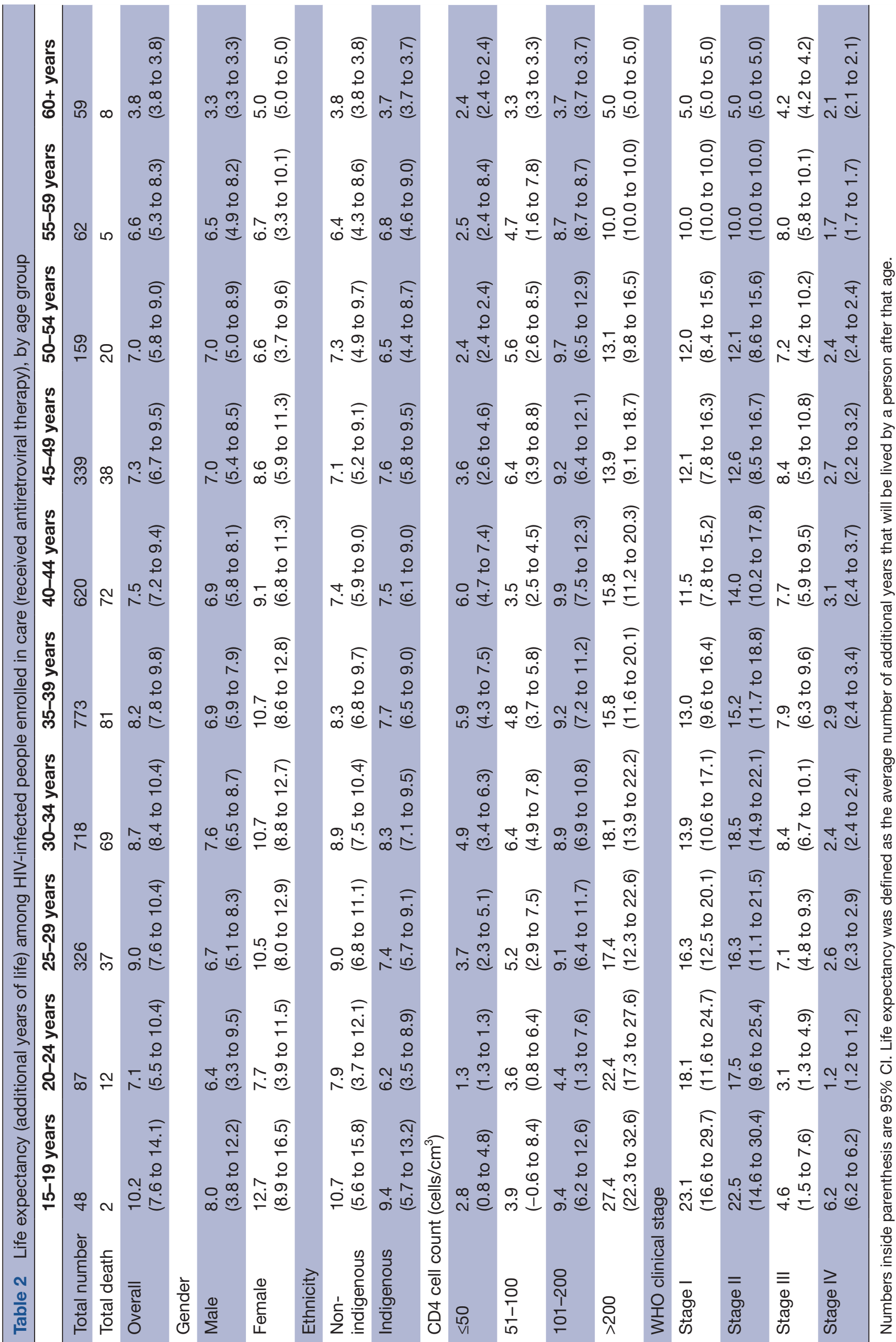


Table 3 HR of mortality among HIV-infected people receiving ART

\begin{tabular}{|c|c|c|c|c|}
\hline \multirow[b]{2}{*}{ Characteristics } & \multicolumn{2}{|l|}{ Univariable } & \multicolumn{2}{|l|}{ Multivariable } \\
\hline & HR (95\% Cl) & $P$ value & HR $(95 \% \mathrm{Cl})$ & $P$ value \\
\hline \multicolumn{5}{|l|}{ Gender } \\
\hline Male & Reference & & Reference & \\
\hline Female & 0.65 (0.51 to 0.82$)$ & $<0.001$ & 0.80 (0.63 to 1.03$)$ & 0.079 \\
\hline \multicolumn{5}{|l|}{ Ethnicity } \\
\hline Non-indigenous & Reference & & Reference & \\
\hline Indigenous & 1.10 (0.89 to 1.36$)$ & 0.381 & 1.07 (0.86 to 1.34$)$ & 0.538 \\
\hline \multicolumn{5}{|l|}{ Age } \\
\hline$\leq 36$ years & Reference & & Reference & \\
\hline$>36$ years & $0.93(0.75$ to 1.15$)$ & 0.511 & 0.74 (0.59 to 0.92$)$ & 0.008 \\
\hline \multicolumn{5}{|l|}{ Residence } \\
\hline Valley & Reference & & Reference & \\
\hline Hill & 0.87 (0.67 to 1.11$)$ & 0.259 & 0.77 (0.60 to 1.01$)$ & 0.057 \\
\hline Terai & $1.11(0.85$ to 1.46$)$ & 0.428 & 0.92 (0.70 to 1.22$)$ & 0.565 \\
\hline \multicolumn{5}{|l|}{ Clinical stage } \\
\hline Stage I & Reference & & Reference & \\
\hline Stage II & 0.81 (0.53 to 1.26$)$ & 0.353 & 0.84 (0.54 to 1.31$)$ & 0.442 \\
\hline Stage III & 2.15 (1.51 to 3.05$)$ & $<0.001$ & 1.82 (1.26 to 2.62 ) & 0.001 \\
\hline Stage IV & 5.86 (4.15 to 8.28$)$ & $<0.001$ & 3.73 (2.58 to 5.41$)$ & $<0.001$ \\
\hline \multicolumn{5}{|c|}{ CD4 cell count (cells/cm³) } \\
\hline$\leq 50$ & Reference & & Reference & \\
\hline $51-100$ & 0.94 (0.70 to 1.26$)$ & 0.675 & 1.06 (0.79 to 1.42$)$ & 0.685 \\
\hline $101-200$ & 0.49 (0.37 to 0.65$)$ & $<0.001$ & 0.71 (0.53 to 0.95$)$ & 0.023 \\
\hline$>200$ & $0.19(0.13$ to 0.29$)$ & $<0.001$ & $0.32(0.21$ to 0.49$)$ & $<0.001$ \\
\hline
\end{tabular}

ART, antiretroviral therapy.

In addition, the results illustrate that life expectancy changed with different variables: women had greater life expectancy gains than men; indigenous people had a relatively shorter life expectancy than non-indigenous people; those with a higher baseline $\mathrm{CD} 4$ cell count value had greater life expectancy; and patients at a lower WHO-classified clinical stage on initiation of ART had greater life expectancy. This study is the first in Nepal to assess the life expectancy of HIV-infected people receiving ART and the disparities in their survival and life expectancies.

Life expectancy was greater among patients with a higher CD4 cell count and at a lower WHO-classified clinical stage when starting ART than in patients of the same age who had a lower CD4 cell count and were at a higher WHO-classified clinical stage. The majority $(84.3 \%)$ of HIV-infected people started ART immediately after their diagnosis. This indicates that people come for diagnosis in the later stages of the infection. Late diagnosis and initiation of ART are common challenges in a resource-limited country. ${ }^{16}$ In addition, compliance with the ART programme after its initiation is rare in a low-income country, while drug resistance and immunological alteration are common. ${ }^{17} 18$ Limited ART centres in the country, geographical difficulties, migration and stigma might be the common reasons behind non-compliance on the ART programme in Nepal. The government required to expand the ART centres and education about the importance of ART. Health systems need to defeat these challenges to increase the life expectancy of the HIV-infected population. Early diagnosis and treatment would help to increase life expectancy among HIV-infected people. Our finding revealed that older age people who reported lower clinical stage and higher CD4 cell count had better life expectancy.

Life expectancy among HIV-infected people receiving ART is low compared with general life expectancy (which is the expected age at death estimated at birth) in Nepal reported in the WHO 2016 report (male $=69$ and female $=72$ years). Most of the indigenous people are hard-to-reach people and have low access to health services, and this might be a possible reason for the low life expectancy among HIV-infected indigenous people compared with non-indigenous people. Clients of sex workers $(33 \%)$ and migrant workers $(10 \%)$ were the key population at higher risk for HIV. ${ }^{19}$ Adverse effects of ART, stigma and migration might be the possible reasons for loss to follow-up. The overall life expectancy was slightly lower at 20-24 years of age, due to late initiation of ART, opportunistic infection and other clinical reasons. 
In addition, this age might represent the migrant workers group which seeks delay in HIV care.

Nepal provides free ART services, with financial assistance provided by the Global Fund to Fight AIDS, Tuberculosis and Malaria since 2004, and ART centres are only available in the limited areas of the country. With the external financial assistance, the Health and Population Ministry in Nepal has expanded ART sites and recommended the initiation of ART for patients with a CD4 cell count threshold of 500 cells $/ \mathrm{cm}^{3}$ or immediately after diagnosis for children, pregnant women who have sex with infected men and female sex workers, to meet the 90-90-90 strategy of the Joint United Nations Programme on HIV and AIDS to reduce mortality and transmission of AIDS and increase ART coverage. ${ }^{20}$ However, the CD4 cell count threshold for initiation of treatment is contentious, ${ }^{21-23}$ but perhaps no longer since the Strategic Timing of Antiretroviral Therapy (START) trial ${ }^{24}$ and treatment as prevention initiative, and the WHO 2016 guidelines on which Nepal's 2017 guidelines ${ }^{25}$ are based. Our study highlights that HIV-infected people who had a higher CD4 cell count at the initiation of ART had a higher life expectancy. Previous studies note that early initiation of ART can reduce the transmission, coinfection and reinfection of the disease..$^{2126-28}$ The baseline value of the $\mathrm{CD} 4$ cell count provides a better understanding of the progression of infection or risk, and a simplified system is needed to encourage immediate treatment. ${ }^{29}$ Nepal required to implement national HIV testing and treatment guidelines 2017 aggressively. ${ }^{25}$ Further research is required to support the Nepal government's policy change to provide ART at an increased CD4 threshold and their continued efforts to improve retention and testing.

This study has several strengths and limitations. One advantage is the large sample size (which enables more accurate estimates of mortality) and the inclusion of a varied, nationally representative HIV-infected population with diverse levels of health. Our assessment of the data on time of HIV diagnosis and time of ART initiation after diagnosis indicates the importance of early diagnosis, initiation of ART and pre-ART care for HIV-infected people. The study's definition of 'failure to follow up' as 3-month consecutive absence from treatment might help reduce the possibility of misclassification bias. A maximum number of patients were transferred to other ART centres and loss to follow-up scenarios could limit the generalisability of our study outcome. Future survival among HIV-infected people in Nepal receiving ART under new guidelines should be comparable with the study's outcome. It would be helpful to reduce the historical bias towards new therapy and new treatment guidelines. ART centres are increased, and new HIV infections and deaths have decreased in Nepal. ${ }^{19}$ Through sensitivity analysis, with an adjustment for those who exited treatment, this study highlights a slightly higher life expectancy among HIV-infected people who received ART.
The limitation of this study is the baseline value of the viral load, which is important for treatment adherence and effectiveness, and was not available for all the HIV-infected people receiving ART during the study period. We could not compare the life expectancy based on different ART threshold treatments because we collected data for this study prior to guidelines that recommended the initiation of ART at a CD4 cell count threshold of 500 cells $/ \mathrm{cm}^{3}$. The study did not consider different clinical markers or conditions at which HIV-infected people initiated ART, other than the low CD4 cell count. Studies from developed countries have analysed life expectancies excluding the high-risk groups of HIV-infected people receiving ART. ${ }^{30-32}$ The missing values of the $\mathrm{CD} 4$ cell count might affect both the survival rate and life expectancy. Abridged life table method did not allow a multivariable analysis of the data adjusting for duration of ART and $\mathrm{CD} 4$ cell count.

\section{CONCLUSION}

Our study results have significant implications for epidemiological and demographic modelling that could estimate the impact of ART on HIV-infected people in resource-poor settings. The early initiation of ART has tremendous benefits: an increase in life expectancy and reduction in mortality. Long-term survival can be expected for those who initiate ART early and with higher $\mathrm{CD} 4$ cell counts. It is therefore vital that the Nepalese government make efforts to establish an innovative health system to provide ART at increased CD4 cell count thresholds, and focus on early detection, testing, sustainable treatment and improved retention.

\section{Author affiliations}

${ }^{1}$ Department of Community Medicine and Public Health, Tribhuvan University, Peoples Dental College, Kathmandu, Nepal

${ }^{2}$ Department of Dentistry, Nepal Medical College Teaching Hospital, Kathmandu, Nepal

${ }^{3}$ Department of Microbiology, Pokhara University, Nobel College, Kathmandu, Nepal ${ }^{4}$ Department of Public Health, Pokhara University, Lekhnath, Nepal

${ }^{5}$ Department of Maternal Health, Institute for Reproductive Health, Kathmandu, Nepal

Acknowledgements We are grateful to Professor Karen Eggleston, Director of Asia Health Policy Program, Deputy Director of Shorenstein Asia-Pacific Research Center (SAPARC), and Senior Fellow of Freeman Spogli Institute for International Studies (FSI), Stanford University and NBER for her efforts with academic editing.

Contributors DNB contributed to the study concept, design, analysis and interpretation of data, and drafted the report. RA contributed to the study concept, interpretation of data and drafted the report. SPW, SK and AKK contributed to the study concept and critical revision of the drafted report.

Funding The authors have not declared a specific grant for this research from any funding agency in the public, commercial or not-for-profit sectors.

Competing interests None declared.

Patient consent for publication Not required.

Ethics approval Ethical approval was obtained from STIDH, Kathmandu, for collection and use of these data (063/071/72). This study is based on secondary data. All the reviewed data had followed the ethical considerations.

Provenance and peer review Not commissioned; externally peer reviewed.

Data availability statement Data are available upon reasonable request. 
Open access This is an open access article distributed in accordance with the Creative Commons Attribution Non Commercial (CC BY-NC 4.0) license, which permits others to distribute, remix, adapt, build upon this work non-commercially, and license their derivative works on different terms, provided the original work is properly cited, appropriate credit is given, any changes made indicated, and the use is non-commercial. See: http://creativecommons.org/licenses/by-nc/4.0/.

\section{REFERENCES}

1. Zwahlen M, Harris R, May M, et al. Mortality of HIV-infected patients starting potent antiretroviral therapy: comparison with the general population in nine industrialized countries. Int J Epidemiol 2009;38:1624-33

2. Mills EJ, Bakanda C, Birungi J, et al. Life expectancy of persons receiving combination antiretroviral therapy in low-income countries: a cohort analysis from Uganda. Ann Intern Med 2011;155:209-16.

3. May M, Gompels M, Delpech V, et al. Impact of late diagnosis and treatment on life expectancy in people with HIV-1: UK Collaborative HIV cohort (UK chiC) study. BMJ 2011;343:d6016.

4. Antiretroviral Therapy Cohort Collaboration. Life expectancy of individuals on combination antiretroviral therapy in high-income countries: a collaborative analysis of 14 cohort studies. The Lancet 2008;372:293-9.

5. Croxford S, Kitching A, Desai S, et al. Mortality and causes of death in people diagnosed with HIV in the era of highly active antiretroviral therapy compared with the general population: an analysis of a national observational cohort. The Lancet Public Health 2016.

6. Nsanzimana S, Remera E, Kanters S, et al. Life expectancy among HIV-positive patients in Rwanda: a retrospective observational cohort study. The Lancet Global Health 2015;3:e169-77.

7. Bor J, Herbst AJ, Newell M-L, et al. Increases in adult life expectancy in rural South Africa: valuing the scale-up of HIV treatment. Science 2013;339:961-5.

8. Johnson LF, Mossong J, Dorrington RE, et al. Life expectancies of South African adults starting antiretroviral treatment: collaborative analysis of cohort studies. PLOS Medicine 2013;10:e1001418.

9. Resch S, Korenromp E, Stover J, et al. Economic returns to investment in AIDS Treatment in low and middle income countries. PLOS ONE 2011;6:e25310.

10. Cooper DA. Life and death in the CART era. The Lancet 2008;372:266-7.

11. Braitstein $P$, Brinkhof MW, Dabis F, et al. Mortality of HIV-1-infected patients in the first year of antiretroviral therapy: comparison between low-income and high-income countries. The Lancet 2006;367.

12. Bor J, Rosen S, Chimbindi N, et al. Mass HIV treatment and sex disparities in life expectancy: demographic surveillance in rural South Africa. PLoS Med 2015;12:e1001905.

13. National Centre for AIDS and STD Control. Nepal Ministry of health Factsheet N4: antiretroviral therapy (art) services in Nepal 2011.

14. National Centre for AIDS and STD Control. Nepal Ministry of health fact sheets on HIV and AIDS 2014.
15. Chiang CL. On constructing current life tables. J Am Stat Assoc 1972:67:538-41.

16. Rosen S, Fox MP. Retention in HIV care between testing and treatment in sub-Saharan Africa: a systematic review. PLoS Med 2011:8:e1001056.

17. Kranzer K, Lewis JJ, Ford N, et al. Treatment interruption in a primary care antiretroviral therapy program in South Africa: cohort analysis of trends and risk factors. J Acquir Immune Defic Syndr 2010;55:e17-23.

18. Kranzer K, Ford N. Unstructured treatment interruption of antiretroviral therapy in clinical practice: a systematic review. Trop Med Int Health 2011;16:1297-313.

19. National Centre for AIDS and STD Control. Fact sheet 1: HIV epidemic update of Nepal Kathmandu, Nepal: Ministry of health 2018.

20. Joint United Nations Programme on HIV/AIDS. 90-90-90: an ambitious treatment target to help end the AIDS epidemic. Geneva: UNAIDS, 2014.

21. Grinsztejn B, Hosseinipour MC, Ribaudo HJ, et al. Effects of early versus delayed initiation of antiretroviral treatment on clinical outcomes of HIV-1 infection: results from the phase 3 HPTN 052 randomised controlled trial. Lancet Infect Dis 2014;14:281-90.

22. Lundgren JD, Babiker AG, Gordin FM, et al. When to start antiretroviral therapy: the need for an evidence base during early HIV infection. BMC Medicine 2013;11.

23. De Cock KM, El-Sadr WM. When to start ART in Africa--an urgent research priority. N Engl J Med 2013;368:886-9.

24. Lundgren JD, Babiker AG, Gordin F, et al. Initiation of antiretroviral therapy in early asymptomatic HIV infection. N Engl J Med 2015;373:795-807.

25. National Centre for AIDS and STD Control. National HIV testing and treatment guidelines Kathmandu, Nepal 2017.

26. Cohen MS, Chen YQ, McCauley M, et al. Prevention of HIV1 infection with early antiretroviral therapy. $N$ Engl $\mathrm{J}$ Med 2011;365:493-505

27. Abdool Karim SS, Naidoo K, Grobler A, et al. Integration of antiretroviral therapy with tuberculosis treatment. N Engl J Med 2011;365:1492-501.

28. Ford N, Meintjes G, Pozniak A, et al. The future role of CD4 cell count for monitoring antiretroviral therapy. Lancet Infect Dis 2015;15:241-7

29. Granich RM, Gilks CF, Dye C, et al. Universal voluntary HIV testing with immediate antiretroviral therapy as a strategy for elimination of HIV transmission: a mathematical model. The Lancet 2009;373:48-57.

30. van Sighem A, Gras L, Reiss P, et al. Life expectancy of recently diagnosed asymptomatic HIV-infected patients approaches that of uninfected individuals. AIDS 2010;24:1527-35.

31. Lohse N, Hansen A-BE, Pedersen G, et al. Survival of persons with and without HIV infection in Denmark, 1995-2005. Ann Intern Med 2007;146:87-95.

32. Nakagawa F, Lodwick RK, Smith CJ, et al. Projected life expectancy of people with HIV according to timing of diagnosis. AIDS 2012;26:335-43. 